\title{
Research on the Contemporary Condition and Countermeasures of Higher Vocational College English Teaching
}

\author{
Xiaomin Zeng \\ Department of Applied Foreign Languages, Dongguan Polytechnic, \\ Dongguan, Guangdong, 523808 China
}

\begin{abstract}
In this paper, we conduct research on the contemporary condition and the countermeasures of the higher vocational college English teaching. In the process of learning a foreign language, the different way of thinking, value system, emotion and language collide with each other, to absorb and fusion, as this is a very complicated process, in which have different culture system for the complex communication and integration. Language as the carrier of culture, it is an important part of culture. As a cultural carrier of language, the content of the culture are recorded in the form of the language and only as a part of the culture, language and the culture system to coordinate and cooperate with each other to promote the continuous development of culture. With this tool, we propose the novel reform paradigm for the higher vocational colleges that will be meaningful.
\end{abstract}

Keywords-Condition, English Teaching, Countermeasures, Vocational College, Review.

\section{Introduction}

Nowadays the society on college students' English practical ability put forward higher requirements, the situation that the domestic college English teaching must be sweeping reforms, and updating the teaching idea, innovating teaching mode, in order to promote the college English teaching effect the effective promotion. Starting from the present status of ordinary university college English teaching in China, analyzes the existing problems in the process of college English teaching, on the basis of this puts forward specific strategies of college English teaching reform in colleges and universities.

The present situation of English teaching in colleges and universities according to literature survey could be summarized as the follows. (1) Old monotonous teaching modes. Students' enthusiasm and creativity of learning English as the traditional pattern of classroom teaching on the one hand to make the lazy students blindly rely on teachers, lack of thinking and creativity as the limit diligent students thinking again on the other hand that bind the play of their potential. (2) Teaching requirement is not reasonable. School teachers are to focus on the pursuit of the pass and tests, objectively reduces the requirement of the students' practical English abilities, the result is like some students said, learnt so many words and corresponding grammar but they will not use. (3) Students complicated structure. Examination-oriented education system and the regional economic development, national regional basic English education have significant differences that cause the students basic English level have bigger difference and caused great difficulties to the college English teaching [1-3].

Level from teaching practice, teachers for students' knowledge, to achieve the effectiveness of the knowledge transfer, precondition condition lies in the English teaching teachers to the grasp of your hand in the class learning, which teachers of English in teaching fully the 
students learning situation analysis should be done before, so that they can do it according to their aptitude. English as the foreign language, and ultimately must be applied to the real life. Therefore in the process of teaching, college English teachers should pay attention to the cultivation of student's practical ability to use English, as pay attention to practice teaching. Practice teaching can be varied the teacher should the new teaching method in teaching practice and daily applications [4].

In this paper, to deal with above mentioned challenges, we conduct research on the contemporary condition and primary countermeasures of higher vocational college English teaching. The teaching reform of higher vocational education needs in the school system and pattern, the curriculum setting, teaching contents and the methods, teaching equipment and practice condition and teachers, teaching evaluation and assessment in line with the requirements of vocational education features. Focus on the reform in school and classroom as the center of traditional talent training mode to push forward the training mode of work-integrated learning, cooperation between colleges. The reform of English education should pay attention to the listed aspects. (1) Reform and innovation is to improve college core competence. In order to achieve the new talents training target and pattern of change, we must broaden the train of thought, a breakthrough on the construction of the connotation and extension.

(2) Economic globalization as the internationalization of education will promote the process of practice teaching reform. Facing with the internationalization of the industry environment, in the face of the internationalization of talent competition, students of higher vocational colleges and universities must have the skilled ability to cope with international competition and cooperation [5].

\section{Direct Method}

> Classroom instruction was conducted exclusively in the target language.

> Only everyday vocabulary and sentences were taught.

- Greater focus on oral communication: skills were built up around question-and-answer exchanges between teachers and students.

> Grammar taught inductively.

> Concrete vocabulary was taught through demonstration, objects, and pictures.

Figure 1. The Key Points of the Vocational College English Teaching

\section{Our Proposed Perspective}

The Higher Vocational Teaching Reform Concepts. Talent cultivation of the higher vocational teaching reform in higher vocational colleges as the instruction, strengthen teaching reform, expand the depth of teaching reform, innovation of teaching reform methods, pay attention to the pragmatic teaching reform with the problem is a common problem faced by all higher vocational colleges.

Higher vocational schools in our country are mainly by the vocational colleges, adult colleges and universities and adjust some of the college professional direction and the training target, converted, merge due to historical reasons and some ideas, held a lot of higher vocational education schools still follow the traditional mode of higher education teaching, namely the organization at the center of the subject teaching, and to maintain the discipline in the arrangement of knowledge on the rigor of the logical structure emphasize its systematicness and integrity. Such teaching reform, the systematicness of the subject as there is no break and the talents cultivation could not embody the new characteristic of vocational education. In higher vocational colleges only change idea, renewing concept, we will accelerate reform of the teaching innovation and breakthrough in the long-term formed according to tradition, with basic experience of organizing teaching and 
management pattern of thinking, actively explore new ways of cultivation of talents with the characteristic of higher vocational education in our country and the new way to keep pace with the times, keep up with the pace of the times development, improving teaching quality and talent training quality in the higher vocational colleges, satisfies the requirement of social development in the quality of higher vocational talents [6-7].

In view of the problems existing in the teaching reform in the vocational colleges, puts forward the trend of the development of higher vocational teaching reform will now development trend of higher vocational teaching reform that are summarized below.

- Based on the characteristics of curriculum to explore suitable teaching methods and effective teaching methods is imminent. The diversification of teaching methods and teaching means can help to improve the teaching quality and students' acceptance of professional knowledge.

- Based on the teaching goal, choose the use of the effective teaching mode. It is specific and complicated practical teaching process, teaching content is rich and diverse, to achieve the primary goal of teaching is also various.

- Along with the continuous renewal of the specialized knowledge that make updates can synchronization of general professional experimental facilities. For training higher vocational students' professional ability and operation ability to provide the necessary hardware.

- Training in accordance with professional standards, to undertake professional responsibility is the main direction of higher vocational education personnel training goal of higher vocational education should be to develop in the direction of professionalization, and enterprises signed the "orders" training with clear field corresponding job orientation training, etc.

In the process of talents training in higher vocational colleges to work closely with the enterprise and work-integrated learning is the best mode of higher vocational education personnel training and the only way. To ensure the smooth implementation of work-integrated learning, vocational colleges must establish an effective, adaptive work-integrated learning personnel training mode of teaching operation mechanism. Schools should not only put the joint design between colleges to develop the training plan, participate in the teaching process and teaching management in the form of a system of rules, but also in the actual operation according to the specific form of work-integrated learning. In the following figure, we show the higher vocational teaching reform orientations. 


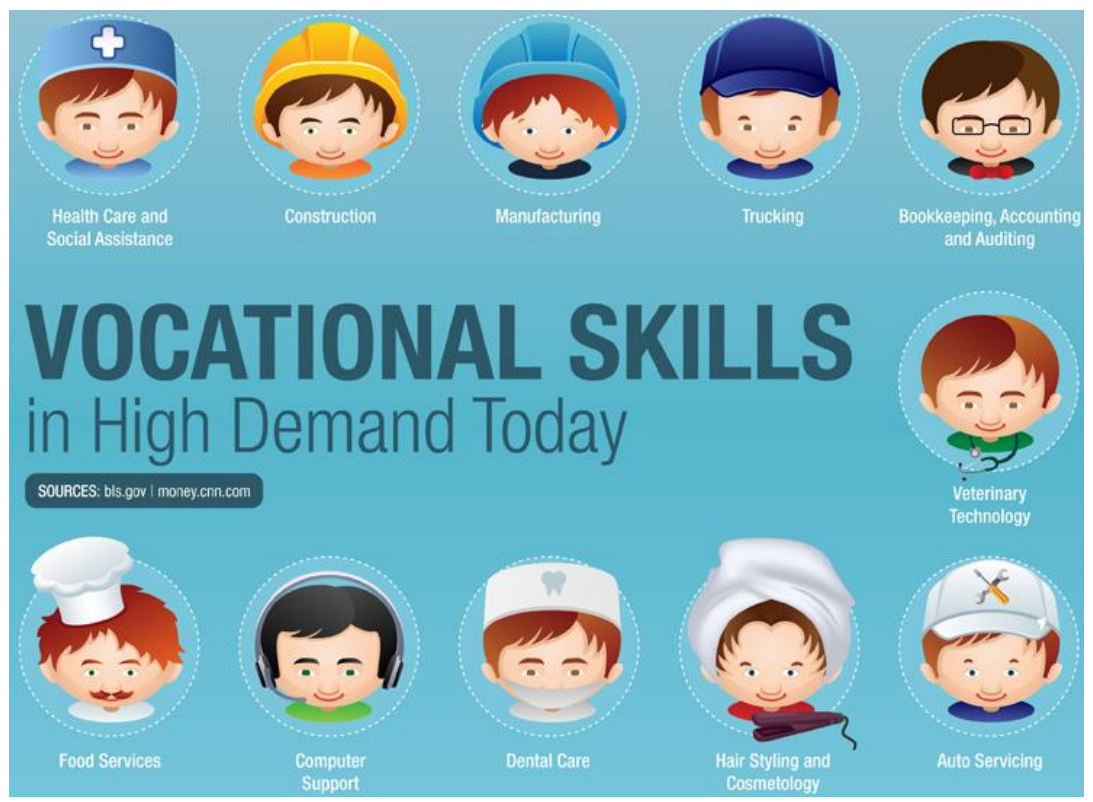

Figure 2. The Higher Vocational Teaching Reform Orientations

The English Education in Colleges. Once mentioned in the former are many domestic colleges and universities based on guarantee the teaching effect of purpose, to set up the teaching supervisor thorough classroom lectures, and arrange a messenger in the students, in order to realize the timely feedback to the teachers' teaching as this way the establishment original intention is to make English teachers to standardize teaching, in order to guarantee the teaching validity [8-9].

College English syllabus for English majors in colleges and universities also specified by the main teaching task: teach fundamental knowledge of English language skills training, the training students' practical ability of using language, professional knowledge and relevant professional knowledge and learning English. Culture teaching is of the great significance in English teaching, college English teachers should combine language teaching and culture teaching, properly handle the relationship between language knowledge skills and cultural background material import, guides the student to understand to adapt to the British and the American cultures, through various channels for students to create the English language environment. English teaching cannot be separated from the language related cultural background knowledge teaching, which requires us to cultivate the students' cultural sensitivity and improve the students' intercultural communicative competence.

College English teaching should not discard culture of pure language skills training or can't stick to the traditional, the cultural background knowledge only as a language learning, and should, from the perspective of the English language itself and guides the student to understand the connotation of the English language and culture, so that the students will culture combine the language knowledge and understanding of the master in the process of English learning process of osmosis to feel the culture.

To achieve the mentioned target, the contemporary colleges have taken the following solutions as the countermeasures. (1) For non-English major students, English teachers should pay attention to in process of teaching English knowledge with the student's professional associated with professional knowledge, and then professional integrity of the teaching goals can be achieved. (2) Considering 
the arrival of the era of the information technology, teachers should be based on a modern information technology to guide students to use the media to autonomous learning, guide students to make full use of network technology development in the direction of the personalized learning. (3) We can adopt the method of the assignments, students interested in the topics and tasks designed by the teacher, then grouped by the students, teachers from the inspiration and let the students feel the charm of English culture from the ordinary mutual discussion.

The Further English Education Reform. In today's rapid development of the higher vocational education, the students' professional skills and comprehensive quality and ability to use language, has become the enterprise the important indicators of the talent. Higher vocational English teachers only English professional basic knowledge and skills, only qualified public English or English teaching, it is far from enough. Today, more emphasis on English teaching and the integration of professional, for professional services will pay more attention to teacher learn professional knowledge, professional knowledge in the teaching. Open college English teaching mode make students break through the boundaries of inside and outside the class and really made it to the teacher as the leading factor, take the student as the main body use of modern information technology and a variety of teaching aids the complete autonomous learning more effectively. To achieve open mode of college English teaching need teachers and the students both sides renew the idea, change in time, teachers should constantly improve knowledge for students to create enough resources for their open to learning [10].

Especially from the perspective of cultural with English education, we suggest the following list for reference. (1) Cultivate and improve cultural empathy, first, to develop cultural sensitivity of the subject of communication. Due to the long life of cultural environment and mind-set, in cross-cultural communication, receive information subject always consciously or unconsciously according to their own cultural background and is decided by the cultural background of decoding way to understand another culture in the spread of information, and according to their own needs to choose and change this information, so that the subject and object of the same information to produce different feelings. (2) Another important link of cultivating the ability of the cultural empathy is to improve the cultural resilience. Adaptation refers to the external environment changes, and the original cognitive structure cannot assimilate new environment when information provided by the individual cognitive structure reorganization and transformation process. (3) In the college English classroom, students organized around culture and cultural differences between mother tongue and target language forms and rich and colorful activities to let the students benefit from the participation, under the atmosphere of the increasing cultural knowledge to consolidate the multicultural knowledge for students.

\section{Conclusion}

In this paper, we conduct research on the contemporary condition and the countermeasures of higher vocational college English teaching. The teaching goal of positioning is directly related to specific follow-up courses setting and the choice of teaching material. If the position is not accurate, inevitably affect the subsequent series of teaching activities carried out smoothly. From a functional perspective, the teaching goal is like a beacon, the direction of the command of all teaching activities any teaching cannot leave correct guidance of the teaching goal. Under this historical background, we propose the countermeasures of higher vocational college English teaching combined with the general education reform and cultural based teaching paradigm that is innovative. 


\section{Reference}

[1] Kirby, Andrew, et al. "Postoperative infections following colorectal surgery in an English teaching hospital." Infectious Diseases 47.11 (2015): 829-833.

[2] Lee, Icy. "Teachers' reflection on implementation of innovative feedback approaches in EFL writing." English Teaching 69.1 (2014): 23-39.

[3] Celce-Murcia, Marianne, and I. W. Yoo. "Discourse-based grammar and the teaching of academic reading and writing in EFL contexts." English Teaching 69.1 (2014): 3-21.

[4] Ning, M. I. "Implications of interlanguage error analysis and research on English language testing and teaching." Higher Education of Social Science 2.2 (2012): 4-7.

[5] Zhu, Biyi, and Yaping Zhou. "A study on students' affective factors in junior high school English teaching." English Language Teaching 5.7 (2012): 33.
[6] Klenowski, Valentina. "The Australian curriculum: Implications for teaching and assessment." Primary English Teaching Association Australia 186 (2012): 1-8.

[7] Rahman, Mizanoor, and Santosh Panda. "Teaching English Through Open Non-Formal Education (Onfe) In Bangladesh With An Effective Integration Of Ict To Support Learning." Turkish Online Journal of Distance Education 13.3 (2012).

[8] Benesch, Sarah. Considering emotions in critical English language teaching: Theories and praxis. Routledge, 2013.

[9] ZHANG, Pan, and Hanbin NIE. "Training Methods for English Speech Contests and Their Effects on English Teaching." (2013): 021.

[10]Jia, Xu. "Listening teaching of university English class B under the Graded teaching mode $[\mathrm{J}]$." Journal of Jiamusi Education Institute 4 (2012): 208. 